\title{
Institutional Quality in Attracting Foreign Direct Investment to Small Countries
}

\author{
Tajul Ariffin Masron ${ }^{a}$ \\ Universiti Sains Malaysia \\ N.A.M. Naseem ${ }^{b}$ \\ Universiti Putra Malaysia \\ Effiezal Aswadi Abdul Wahabc \\ Curtin University
}

\begin{abstract}
Institutional quality (IQ) has been proven by many studies as generating positive impact to economic development, including via luring more foreign direct investment (FDI) inflows. However, the inconsistent reality relating to FDI inflows and IQ of the host countries, especially in small countries has led this study to re-examine the effectiveness of IQ in promoting FDI inflows. Hence, selecting small countries in four regions located around four large countries, namely Brazil, Russia, India and China (BRIC) as a case study, results confirmed that the effectiveness of IQ is gradually eroded if IQ in BRIC is also relatively improved.
\end{abstract}

Keywords: Developing countries, FDI, institutional quality

JEL classification: F4, $\mathrm{O5}$

\section{Introduction}

The positive role of institutional quality on economic development has been generally supported by numerous studies (Asiedu \& Lien, 2011; Bénassy-Quéré, Coupet, \& Mayer, 2007; Buchanan, Le, \& Rishi, 2012; Cole, Elliott, \& Zhang, 2009; Daniele \& Marani, 2011; Globerman \& Shapiro, 2002; Goswami \& Haider, 2014; Hyun, 2006; Masron \& Nor, 2013). Some studies (see Eichengreen \& Tong, 2007; Liu, Chow, \& Li, 2007; Ravenhill, 2006; Wang, Wei, \& Liu, 2007; Yang, 2006) have suggested that because large countries have a larger market size - e.g., China's market is almost double that of the Association of Southeast Asian nations (ASEAN) markets combined - small improvements in institutional quality in small countries may be insufficient to offset the attractiveness of large countries.

Although large countries such as BRIC can rely on their huge domestic markets to attract multinational corporations (MNCs) to bring in their long-term investment,

\footnotetext{
School of Management, Universiti Sains Malaysia, 11800 Minden, Penang, Malaysia. Email: tams@usm.my

Department of Economics, Faculty of Economics and Management, Universiti Putra Malaysia, 43400 Serdang, Selangor, Malaysia. Email: naseemniaz@upm.edu.my (Corresponding author)

School of Accounting, Curtin Business School, Curtin University, Western Australia, Australia. Email: effiezal.abdulwahab@curtin.edu.au
} 
which is also known as foreign direct investment (FDI), improvement of institutional quality (IQ) is also considered as mandatory (see Teixeira \& Guimarães, 2015). The importance of good IQ is not only meant to attract FDI, but also to promote other economic activities such as exports, imports and domestic investments (Bojnec, Ferto,, \& Fogarasi, 2014). Hence, BRIC have also from time to time invested serious efforts to improve their IQ levels. If this is true, then past studies on IQ-FDI nexus suggesting improvement in IQ will automatically bring in more FDI inflows could be a misleading conclusion and require a more in depth study to rectify. In other words, while the large market size is already an advantage to BRIC, improvement in IQ may further make them favourable to MNCs. Even if the improvement in IQ of BRIC may not be as good as the positive change in the surrounding small countries' $I Q$, it may be enough to make the change in small countries' IQ deem ineffective to lure FDI inflows to them. The role of IQ is then a necessary but insufficient condition for FDI inflows, especially to smaller countries.

In line with the above situation in several continents, Asiedu (2004) viewed that improvements in the institutional quality of many African countries do not result in significant improvement in FDI inflows. The possible reason for this failure is that the improvement in one's policy environment with respect to its past value will not be efficient to attract FDI inflows (Asiedu, 2004). Absolute strategy, which is focusing on improving IQ relative to its past value can be regarded as short-term strategy, just for the sake of take-off. However, in the longer term, a host country aiming to lure more FDI should focus on relative improvements. Significant relative improvement is necessary to attract multinational corporations (MNCs). Another similar study, Zhuang, de Dios and Martin (2010) focussed more on the threshold effect of the global average of IQ on several aspects, such as government effectiveness, regulatory quality and rule of law. Zhuang et al. (2010) suggested that developing Asian economies with IQ above the global average tend to grow faster than those economies scoring below the global average. Having discussed the point above, the objective of this study is to investigate the implications of changes in large countries' IQ on FDI inflows into the surrounding small countries in four regions. The four regions are ASEAN, South Asia, Latin America and the transitional economies. With the exception to Zhuang et al. (2010), this issue has been receiving limited attention by past studies and can be treated as the primary contribution of this study.

The rest of this paper is organised as follows. The next section reviews past studies, followed by a discussion of the methodology in the third section. The fourth section presents the results, and the fifth section concludes.

\section{Literature Review}

The poor institutional quality of host countries is cited by several studies as the main factor deterring the inflow of FDI (Asiedu, 2006; Alfaro, Kalemli-Ozcan, \& Volosovych, 2008; Bénassy-Quéré et al., 2007; Buchanan et al., 2012; Goswami \& Haider, 2014; Julio \& Yook, 2016; Kinda, 2016; Masron \& Nor, 2013; Oluwatobi, Efobi, Olurinola, \& Alege, 2015; Papaioannou, 2009; Sánchez-Martín, de Arce, \& Escribano, 2014; Shah, Ahmad, \& 
Ahmed, 2016). However, it is unlikely the FDI-IQ nexus is fully resolved or explained by these studies. The case of resource-rich developing countries that have received huge amounts of FDI in natural resources in the absence of good institutional quality creates the paradox. Aleksynska and Havrylchyk (2013) provided two possible explanations. Firstly, a rentier effect from revenues of fuel exports allows the government to buy off critics (with, for instance, lavish infrastructure projects) and avoid accountability pressure, resulting in the discouragement of the development of better institutions. The second possible explanation is to follow Bénassy-Quéré et al. (2007), Cezar and Escobar (2015) and Habib and Zurawicki (2002), who instead of considering solely the quality of institutions in host countries, shifted the focus to the role of institutional distance between the origin and destination countries. Aleksynska and Havrylchyk (2013) are the latest followers of this idea, observing that institutional differences play a significant role in explaining FDI inflows from the south. Aleksynska and Havrylchyk (2013) extended the idea by investigating the implications of two different scenarios: namely when the difference in IQ is either negative or positive. Another paradox is the huge inflows of FDI into China when IQ in China is still at a low level. ${ }^{1}$ For instance, OECD (2000) stated that for twenty years (1979-1999), actual FDI inflows into China from 1979 to 1999 amounted to US\$306 billion, which is equivalent to 10 percent of direct investment worldwide and about 30 percent of the investment amount for all the developing countries put together. The latest UNCTAD report on World Investment Perceptions lists China in first place among the top 15 investment locations. Hong Kong SAR and Taiwan, China have traditionally been the most important sources of FDI, but the presence of investors from Japan, the USA and Europe has grown over the years (World Bank, 2010). With slight improvement, but believed as huge by investors, a big country like China has been successful in attracting FDI, leaving small countries surrounding it to receive a very minimum inflow of FDI. Unfortunately, most past studies, while admitting this issue, tend to ignore this point when dealing with FDI-IQ research. This study then can be considered as among the first few to examine the effectiveness of a country's IQ in luring FDI inflows when nearby FDI-competing big country's IQ is also getting better, even slightly.

Market size has been suggested in almost all studies pertaining to FDI inflows as the primary factor affecting a firm's decision to invest. Among the studies making this claim are Alfaro et al. (2008), Bénassy-Quéré et al. (2007), Buch and Lipponer (2007), Hong (2008), Papaioannou (2009) and many others. A good explanation regarding the importance of market size is given by Schneider and Frey (1985) that market size is an important premise because market growth is contingent on the efficient utilisation of resources and exploitation of economies of scale. The importance and role of natural resources in attracting FDI inflows has been stressed by several studies, such as Aleksynska and Havrylchyk (2013), Asiedu and Lien (2011), Cleeve (2008), Ndikumana

1 As shown by Masron (2017), information concerning six elements of institutional quality tabulated in Table I failed to show a significant improvement of China's IQ. Similarly, Masron and Naseem (2017) demonstrated that for the average IQ of 2004-2008, ASEAN countries are merely at par to BRIC. 
and Verick (2008) and Neumayer and Spess (2005). The inclusion of natural resource intensity is to control for the fact that large natural resources are a major attractor of foreign investors. Huge reserves of natural resources surely attract more FDI inflows, as is the case of resource-rich African countries. Asiedu and Lien (2011) argued that the importance of natural resources is threefold: natural resources indicate the type of FDI that goes to the host country, play a crucial role in the economic development of the host country and constitute an essential variable in the FDI equation. One of the motivations of FDI inflows is resource seeking, and the inclusion of a natural resource variable may help to determine whether multinational corporations fall under this type or not. The only point that differentiates one study to another is on the measurement of natural resources. For instance, Asiedu and Lien (2011) applied three proxies, namely the share of fuel in total merchandise exports, the share of minerals in total merchandise exports, and the share of fuel and minerals in total merchandise exports. However, Goswami and Haider (2014) argued that the relative importance of natural resources in terms of the host country's FDI has declined since the 1960s and 1970s.

Tuan and $\mathrm{Ng}$ (2004) outlined three phases of agglomeration in China: (i) the agglomeration of a core-peripheral system (CPS), (ii) the city as an agglomeration, and (iii) intra-industry agglomeration. The third phase is relevant for describing the creation of an East Asian network, later translated into agglomeration economies. The idea is that small firms that belong to the same or different supporting industry groups may have gone through division of labour processes and eventually cut down their size of operations to remain competitive in the very competitive business environment. Being small, they rely heavily on networking and support facilities for efficient production. The existence of a good supply chain or processes will earn them low transaction costs and probably high revenues. This idea is further elaborated by Du, Lu and Tao (2008), who divided agglomeration into two categories: (i) horizontal agglomeration, referring to either FDI source country firms engaging in the same industry in the same region or domestic enterprises engaging in the same industry in the same region, and (ii) vertical agglomeration, referring to the concentration of firms with backward and forward linkages to multinational corporations. Among the benefits of vertical agglomeration in a region is an increase in the variety of intermediate inputs or final goods available and lower average purchasing costs, as well as knowledge spillover through learning (Du et al., 2008). Bronzini (2007) and Hong (2008) are among the recent studies who confirmed the crucial role played by agglomeration or production networking in shaping the geographical pattern of FDI. Tuan and Ng (2004) highlighted the success stories of agglomeration economies between the Pearl River Delta of China and Hong Kong, and the same scenario can be considered to happen with a larger scope between ASEAN and China. ${ }^{2}$

2 In this study, networking is proxied by the total trade between each ASEAN country and China. Apart from being a proxy for networking, trade itself is a crucial factor in almost all modelling of FDI. As mentioned by Torrisi (1985), trade surplus is an indication of a dynamic and healthy economy, which in turn indicates a greater likelihood to lure FDI. High exports also mean the country is practising open economic policies, which are generally favourable to businesses. 


\section{Methodology}

\subsection{Modelling Strategy}

As for estimating the model, this study is broadly similar to the model proposed by Busse and Hefeker (2007) as the baseline with slight modifications. The original model by Busse and Hefeker (2007) consisted of inflation and gross national income growth, which are dropped in this study and replaced by natural resources and infrastructure in the second model. Labour costs are not included for several reasons. First, no labour cost information is available. Studies such as Masron and Nor (2013) attempted to investigate this information but found it to be insignificant in the second model. The finding that impact of wages may not be a significant determinant of FDI inflows is consistent with other past studies, such as Lipsey (1999), Loree and Guisinger (1995) and Wheeler and Mody (1992). Combined with the unavailability of accurate labour cost information, these few studies are sufficient to justify the exclusion of a labour cost variable. Using inflation as a proxy for macroeconomic inadequacy also lack support. For instance, the results of inflation on FDI in Buch and Lipponer (2007), although statistically significant, do not show a significant size of impact. In other words, the effect is negligible in size. This likely unimportant role of inflation has also been found by other studies such as Alfaro, Chanda, Kalemli-Ozcan and Sayek (2004), Buchanan et al. (2012) and Busse and Hefeker (2007), who observed that inflation has an insignificant role in terms of FDI inflows. Hence, this study does not include the variable. ${ }^{3}$ Our modified baseline model is as follows: ${ }^{4}$

$$
\operatorname{lnFDI} I_{i, t}=\beta_{0}+\beta_{1} \operatorname{lnGDP_{i,t}}+\beta_{2} E X P_{i, t}+\beta_{3} \operatorname{In} I Q_{i, t}+\beta_{4}\left(\operatorname{In} I Q_{i, t} * G A P_{i, t}\right)+\varepsilon_{i, t}
$$

where $F D I$ is foreign direct investment inflows to the host country, GDP is the market size of host country, EXP is the networking level between the host country and the major competing country, $I Q$ is the institutional quality of the host country, GAP is institutional quality gap or distance between IQ in competing large country $\left(I Q_{B C}\right)$ and IQ in host small country $\left(I Q_{s c}\right)$. The formula for GAP is as follows:

$$
G A P=\left(\ln \left|Q_{B C}-\ln \right| Q_{S C}\right)
$$

The GAP implies that if $I Q_{B C}>I Q_{S C}$, host small country's $I Q$ may be deem less effective to lure FDI inflows and vice versa. The GAP also, if statistically significant, verifies that the larger the GAP, the more effective will be FDI inflows to host small country. All variables are entered in logarithmic form $(I n)$, except for GAP.

3 This study, however, has tested the model with inflation, but the results do not alter the findings presented in this study. The results with inflation in the equation are available upon request from the corresponding author.

4 The second model is basically rerunning the model (1) using quarterly data, which was also complemented by augmented model with two additional explanatory variables. These strategies are meant to confirm the stability of the results in the original model using annual data as equation (1). 
Table 1. Summary of variables and sources

\begin{tabular}{|c|c|c|}
\hline Variable & Measurement & Sources \\
\hline FDI & $\begin{array}{l}\text { Inward foreign direct invest- } \\
\text { ment into small countries }\end{array}$ & UNCTADstat (UNCTAD, 2014) \\
\hline GDP & Gross domestic product & World Development Indicators (World Bank, 2014a) \\
\hline EXP & $\begin{array}{l}\text { Trade between each small } \\
\text { and large countries }\end{array}$ & UNCTADstat (UNCTAD, 2014) \\
\hline IQBC, IQSC & Governance index & $\begin{array}{l}\text { Worldwide Governance Indicators (World Bank, } \\
\text { 2014b) }\end{array}$ \\
\hline GAP & $\begin{array}{l}\text { GAP in IQ of big and small } \\
\text { countries }\end{array}$ & Own calculation based on World Bank (2014b) \\
\hline INFRA & Telephone line & World Development Indicators (World Bank, 2014a) \\
\hline NATR & $\begin{array}{l}\text { Depletion of natural } \\
\text { resources as a \% of GDP }\end{array}$ & World Development Indicators (World Bank, 2014a) \\
\hline
\end{tabular}

Note: $\mathrm{IQ}_{\mathrm{BC}}$ is $\mathrm{IQ}$ of competing big countries and $\mathrm{IQ}_{\mathrm{SC}}$ is $\mathrm{IQ}$ for small countries. They are calculated based on the six elements of governance index, namely (i) voice and accountability, (ii) political stability and absence of violence/terrorism, (iii) government effectiveness, (iv) regulatory quality, (v) rule of law and (vi) control of corruption. INFRA and NATR are only available in the augmented model of equation (1).

Table 1 summarises all variables used in this study, which covers the period from 1996 to 2012. Brunei, Myanmar and Timor Leste are excluded from the ASEAN list due to missing information. For Latin America, the Falkland Islands are excluded, whereas for the transition economies and South Asia, Montenegro and Afghanistan are excluded, respectively. The exclusion is primarily because of poor information. Iran, in contrast, is excluded from the list of South Asian countries, which is based on UNCTAD, due to different treatment.

As part of robustness test, this study conducted analysis which utilised quarterly data for the same model of equation (1). In addition, as quarterly data allows for more explanatory variables to be included, this study also extended equation (1) to also include additional control variables which is deemed as crucial by past studies such as infrastructure (Robbins \& Perkins, 2012; Tran, 2009) and natural resources (see Aleksynska \& Havrylchyk, 2013; Asiedu \& Lien, 2011; Ji, Magnus, \& Wang, 2014; Ndikumana \& Verick, 2008; Neumayer \& Spess, 2005).

\subsection{Estimation Procedure}

For the purpose of this study, we employ the panel unit root of Im, Pesaran and Shin (2003, IPS) as a prior test to pooled mean group (PMG) analysis in order to determine the order of integration of the variables. This IPS test is well-known in terms of being less restrictive and more powerful as compared to the other unit root tests as established by Breitung (2000) and Levin, Lin and Chu (2002), which do not allow heterogeneity in the autoregressive coefficient. In addition, IPS leads to a solution to Levin et al.'s serial correlation problem by assuming heterogeneity between units in 
a dynamic panel framework. The basic equation for the IPS panel unit root test that specifies an Augmented Dickey-Fuller (ADF) regression with an individual intercept and a time trend for each cross section can be written in the following forms:

$$
y_{i t}=\delta_{i}+\rho_{i} y_{i, t-1}+\sum_{j=1}^{\rho i} \phi_{i j} \Delta y_{i, t-j}+\varepsilon_{i t} ; \quad i=1,2, \ldots, T
$$

where $y_{i t}$ presents a selected variable under consideration in country $i$ and year $t . \delta_{i}$ is the individual fixed effect while $\rho$ is selected to make the residuals uncorrelated over time. The null hypothesis is that $\rho_{i}=0$ for all $i$ against the alternative hypothesis, which is that $\rho_{i}<0$ for some $i=1 \ldots N_{1}$ and $\rho_{i}=0$ or $i=N_{1}+1 \ldots \ldots . N$. Hence, the IPS statistics which is based on ADF statistics to generate a standardised test can be derived as follows:

$$
\bar{t}=\frac{1}{N} \sum_{t=1}^{N} t_{i T}
$$

where $t_{i T}$ is the ADF t-statistic for country $i$ based on the country-specific ADF regression, as in Equation (3). The $t$-statistic is assumed to be normally distributed under $H_{o}$ and the critical value for given values of $N$ and $T$ are provided in Im et al. (2003). Indeed, the series is said to be integrated if the series become stationary after first differentiation, i.e. $y_{i t} \sim 1(1)$.

Based on the order of stationarity that has been identified, this study proceeds to verify whether there exists long-run relationship among the variables using the bound test proposed by Pesaran, Shin and Smith (2001). As opposed to other approaches such as Engle and Granger (1987), vector error correction model (VECM) by Johansen and Juselius (1990), fully modified OLS (FMOLS) by Pedroni (1999), dynamic OLS (DOLS) by Kao and Chiang (2001), autoregressive distributed lag (ARDL) model allows the relationship to be estimated by ordinary least square (OLS) if the lag order of the model is identified (Fosu \& Magnus, 2006). More importantly, ARDL approach tends to offer robust results for a small sample analysis (Narayan \& Narayan, 2005; Narayan \& Smyth, 2006; Omtzigt \& Fachin, 2006).

For dynamic analysis, the equation by ARDL method can be expressed as the following error correction equation:

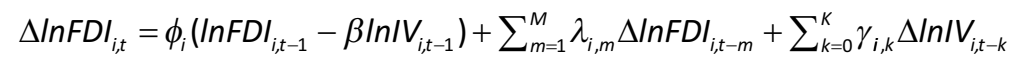

or

$$
\Delta / n F D I_{i, t}=\phi_{i} E C T_{i, t-1}+\sum_{m=1}^{M} \lambda_{i, m} \Delta / n F D I_{i, t-m}+\sum_{k=0}^{K} \gamma_{i, k} \Delta / n I V_{i, t-k}
$$

where $i$ denotes the country, $t$ is time, $F D I$ is the inflow of FDI, $I V$ is a matrix of all independent variables, $\varepsilon$ is an error term and ECT is error correction term. The parameter vectors $\phi$ and $\beta$ respectively capture the error correction and homogenous long-run effect of all IV, while $\lambda$ and $\gamma$ capture the heterogeneous short-run responses. The cointegration test which is known as bound test under ARDL framework can be carried out by imposing zero condition to all long-run multipliers. Theoretically, the presence of cointegration or long-run relationship can be confirmed by restricting all estimated coefficients of lagged level variables to zero $\left(H_{0}: \phi=\phi \beta=0\right)$. The alternative 
hypothesis is $H_{a}: \phi \neq \phi \beta \neq 0$. If the computed F-value is less than the lower bound critical value, we do not reject the null hypothesis of no cointegration. Conversely, if the computed F-value is greater than upper bound critical value, we accept the alternative hypothesis that there is a steady state equilibrium among the variables. Finally, if the computed F-value falls between lower and upper bound critical value, the result is inconclusive. As an alternative, in this study, we confirm the presence of cointegration based on the significant ECT (as shown in equation 5) as suggested by Kremers, Ericsson and Dolado (1992). Kremers et al. (1992) argued that ECT can be utilised as the test for cointegration. The significant ECT means all variables are cointegrated and we can conclude that there is a long run relationship among the variables. Prior to this, as shown in equations 5 and 6 , the selection of lag order $M$ and $K$ is to be done before the whole equation can be estimated. Referring to Pesaran and Shin (1995), who argued that Schwartz Bayesian Criterion (SBC) is more preferred than Akaike Information Criterion (AIC), this study will refer to SBC as the selection criterion. According to Davidson and MacKinnon (2004), asymptotically, SBC would pick the more parsimonious model than AIC might suggest. Prior to this study, Koehler and Murphree (1988) also suggested the superiority of SBC over AIC. Therefore, SBC is chosen instead of AIC.

Once we confirm the existence of cointegration, which is based on ECT, ARDL will be referred to as it allows for a dynamic specification in which short- and longrun effects differ, and heterogeneous constants and marginal short-run effects across countries can be accommodated. It also maintains the homogeneity of long-run responses and the estimation does not require long lag structures. Endogeneity problem is probably the primary source of unease over the reliability of many studies in the past despite various attempts to control for this. In this regard, Pesaran, Shin and Smith (1999) contends that the PMG (ARDL) approach continues to be applicable even if the independent variables are endogenous.

Table 2 presents the list of countries under study. Four regions are chosen, namely South Asia, South East Asia (ASEAN), Latin America and transition economies. The

Table 2. List of countries

\begin{tabular}{llllll}
\hline \multicolumn{5}{c}{ Small countries } \\
\hline South Asia & ASEAN & \multicolumn{2}{c}{ Latin America } & \multicolumn{2}{c}{ Transition economies } \\
\hline Bangladesh & Cambodia & Argentina & Paraguay & Albania & Moldova \\
Bhutan & Indonesia & Bolivia & Peru & Armenia & Tajikistan \\
Maldives & Laos & Chile & Suriname & Azerbaijan & Macedonia \\
Nepal & Malaysia & Colombia & Uruguay & Belarus & Turkmenia \\
Pakistan & Philippines & Ecuador & Venezuela & Georgia & Ukraine \\
Sri Lanka & Singapore & Guyana & & Kazakhstan & Uzbekistan \\
& Thailand & & & Kyrgyzstan & Bosnia-Herzegovina \\
& Vietnam & & & & \\
\hline
\end{tabular}

Large countries

\begin{tabular}{llll}
\hline India & China & Brazil & Russia \\
\hline
\end{tabular}

Note: The list is based on UNCTAD but excludes Iran from the list of countries categorised under South Asia. 
corresponding large countries for each of these regions are India, China, Brazil and Russia. Several countries are not included due primarily to poor data. The study period is from 1996 to 2012 and both annual as well as quarterly data are utilised and tested.

\section{Findings and Discussion}

Table 3 reports the results for panel unit root test based on IPS (2003). The table demonstrates that the null hypothesis of the unit roots for the panel data of FDI, exports $(E X P)$, interaction terms $\left(I Q^{*} G A P\right)$, natural resources (NATR) and infrastructure (INFRA) cannot be rejected in level. However, they are able to reject the hypothesis when the series are in first difference. For GDP and $I Q$, the null hypothesis of unit root can be rejected at level as well as at first difference. With the results of integration order or stationarity, we can conclude that the preferred model should be the dynamic model. With the mixture of integration order of the variables, VECM, FMOLS and DOLS are no longer applicable methods. We are left with ARDL to proceed with, which can allow for mix order of integration.

Table 3. IPS panel unit root test

\begin{tabular}{|c|c|c|c|c|}
\hline & \multicolumn{2}{|c|}{ Level } & \multicolumn{2}{|c|}{ 1st difference } \\
\hline & $\mathrm{C}$ & $C \& T$ & C & $C \& T$ \\
\hline & \multicolumn{4}{|c|}{ Annual } \\
\hline InFDI & 2.8686 & -0.1024 & $-10.8515^{* * *}$ & $-8.7682 * * *$ \\
\hline InGDP & $10.8492^{* * *}$ & $-3.5479 * * *$ & $-8.6933 * * *$ & $-6.6835 * * *$ \\
\hline InEXP & 3.2771 & -1.2135 & $-9.3054 * * *$ & $-5.9583 * * *$ \\
\hline $\ln I Q$ & $-7.1150 * * *$ & $-4.4791 * * *$ & $-11.1716^{* * *}$ & $-6.6748 * * *$ \\
\hline \multirow[t]{2}{*}{$\ln I Q * G A P$} & $-1.6663 * * *$ & -1.0889 & $-10.0144 * * *$ & $-6.4472 * * *$ \\
\hline & \multicolumn{4}{|c|}{ Quarterly } \\
\hline InINFRA & 0.4226 & 1.6858 & $-23.2729 * * *$ & $-23.3395 * * *$ \\
\hline InNATR & $-2.0073 * *$ & -1.0884 & $-45.8110 * * *$ & $-45.4236 * * *$ \\
\hline
\end{tabular}

Having confirmed the integration order of each series, the next analysis will focus on the presence of long-run relationship or cointegration via the ECT. As demonstrated in Table 4, ECTs in all three models verify the presence of cointegration as they are significant at 1 percent. In addition, a negative and significant ECT implies how quickly variables adjust the short-run disequilibrium. A relatively low ECT in the case of models $2 \mathrm{a}$ and $2 \mathrm{~b}$ could be reasonable as the model is estimated by using quarterly data. Taking into account the quarterly results, the effect of adjustment turns out to imply that the adjustment process is slow. Although this explanation requires more detail 
Table 4. Error correction model [Dep. Var. $=\Delta \operatorname{lnFDI}]$

\begin{tabular}{|c|c|c|c|c|c|c|}
\hline & \multicolumn{2}{|c|}{ Model 1} & \multicolumn{2}{|c|}{ Model 2a } & \multicolumn{2}{|c|}{ Model 2b } \\
\hline & Lag 0 & Lag 1 & Lag 0 & Lag 1 & Lag 0 & Lag 1 \\
\hline C & $\begin{array}{l}-0.961 * * * \\
(-2.780)\end{array}$ & - & $\begin{array}{l}-1.013 * * * \\
(-4.164)\end{array}$ & - & $\begin{array}{l}-1.103 * * * \\
(-4.156)\end{array}$ & - \\
\hline ECT(-1) & - & $\begin{array}{l}-0.307^{* * *} \\
(-3.515)\end{array}$ & - & $\begin{array}{l}-0.056^{* * *} \\
(-4.300)\end{array}$ & - & $\begin{array}{l}-0.059 * * * \\
(-4.208)\end{array}$ \\
\hline$\Delta \operatorname{lnFDI}$ & - & $\begin{array}{l}-0.202^{* * *} \\
(-3.127)\end{array}$ & - & - & - & $\begin{array}{c}0.015^{* *} \\
(2.178)\end{array}$ \\
\hline$\Delta \operatorname{lnGDP}$ & $\begin{array}{c}1.024 \\
(1.002)\end{array}$ & $\begin{array}{c}0.496 \\
(0.452)\end{array}$ & $\begin{array}{l}0.979 * * * \\
(2.706)\end{array}$ & - & $\begin{array}{l}1.159 * * * \\
(2.919)\end{array}$ & - \\
\hline$\Delta \operatorname{lnEXP}$ & $\begin{array}{c}0.036 \\
(0.351)\end{array}$ & $\begin{array}{c}-0.032 \\
(-0.199)\end{array}$ & $\begin{array}{c}-0.128 \\
(-1.604)\end{array}$ & - & $\begin{array}{l}-0.190^{* *} \\
(-2.134)\end{array}$ & - \\
\hline$\Delta \ln \mid \mathrm{Q}$ & $\begin{array}{c}-0.366 \\
(-0.836)\end{array}$ & $\begin{array}{c}0.378 \\
(0.470)\end{array}$ & $\begin{array}{c}-0.115 \\
(-0.304)\end{array}$ & - & $\begin{array}{l}-0.113 \\
(0.847)\end{array}$ & - \\
\hline$\Delta \ln I Q^{*} \mathrm{GAP}$ & $\begin{array}{c}-0.025 \\
(-0.846)\end{array}$ & $\begin{array}{c}0.546 \\
(1.019)\end{array}$ & $\begin{array}{c}-0.096 \\
(-1.234)\end{array}$ & - & $\begin{array}{l}-0.084 \\
(0.883)\end{array}$ & - \\
\hline$\triangle$ InINFRA & - & - & - & - & $\begin{array}{c}-0.184 \\
(-0.773)\end{array}$ & - \\
\hline$\Delta \operatorname{lnNATR}$ & - & - & - & - & $\begin{array}{c}-2.862 \\
(-0.996)\end{array}$ & - \\
\hline
\end{tabular}

\begin{tabular}{llcc}
\hline & \multicolumn{3}{c}{ Bound test } \\
\hline F-test & $6.72^{* * *}$ & $12.85^{* * *}$ & $10.26^{* * *}$ \\
$1 \%$ Critical value & 5.61 & & \\
\hline
\end{tabular}

\begin{tabular}{lccc}
\hline \multicolumn{3}{c}{ Model Criteria } \\
\hline S.E. of Reg. & 0.279 & 0.1434 & 0.1426 \\
SIC & -0.636 & -3.4323 & -3.1806 \\
Normality $^{\mathrm{a}}$ & $0.791[0.672]$ & $1.021[0.605]$ & $4.444[0.112]$ \\
Serial corr. $^{\mathrm{b}}$ & $0.348[0.713]$ & $1.283[0.326]$ & $0.107[0.893]$ \\
Heterogeneity $^{\mathrm{c}}$ & $0.396[0.547]$ & $1.184[0.294]$ & $1.442[0.139]$ \\
\hline
\end{tabular}

Note: $* *$ and $* * *$ denote significance at $5 \%$ and $1 \%$ critical values, respectively. $t$-value is in parenthesis (). ${ }^{a}$ Jarque-Bera Test is the test for normality. ${ }^{b}$ Breusch-Pagan LM Test is the test for serial correlation. c White Test is the test statistic for possible presence of heteroscedasticity. Stability test is conducted by using CUSUM test and available upon request.

analysis to confirm, the plausible explanation of the slow adjustment could reflect the fact that to process to improve IQ level, which comprises of six elements, is not an easy thing to be done. To make things worse, the effectiveness of IQ largely depends on the improvement in IQ vis-à-vis competitors' IQ level, making the strategy that utilising IQ to lure FDI inflows really consumes time to be successful. ARDL constrains the longrun coefficients to be homogenous to all countries but it allows for variation in the short-run coefficients, intercept and error variance across countries. However, with 
39 countries under this study, to show the results corresponding to each country will consume a lot of pages. Hence, this study only discusses the average or common shortrun effect as shown in Table 4.

The results of long-run relationship are presented in Table 5. As shown, GDP, exports and IQ are all consistent with expectation and past studies that they significantly and positively affect FDI inflows. The outcome is also relatively stable in size regardless of the model. Model 1 , which utilises annual data, have slightly lower impact on FDI as compared to Model $2 \mathrm{a}$ but at comparable size. Nevertheless, IQ and the interaction term are found to be insignificant in the short run. The probable explanation could be because IQ can be changed but it is not expected to have a big impact in the short run. This could be why both are insignificant in the short-run model. Model 2a employs quarterly data for the same equation (1) and is estimated as part of robustness checking of the results in Model 1 . The robustness check is further extended by expanding the model to incorporate other variables deemed as significant by past studies in Model $2 \mathrm{~b}$. Unfortunately, the additional variables of natural resources (NATR) and infrastructure (proxied by telephone services) do not show significant influence on FDI inflows in Model 2b. More importantly, the inclusion of these two explanatory variables does not alter significantly the effect of GDP, exports, IQ and also the interaction term of $\ln I Q$ and IQ gap $\left(\ln / Q^{*} G A P\right)$. This study also tested the model by including other variables, apart from infrastructure and natural resources, such as world FDI, money supply and literacy. However, the results remain the same and to conserve space, are not reported here (available upon request).

Moving on to our focal variable, which is the interaction term of IQ and GAP, as expected the variable enters significantly and negatively in all models. This

Table 5. Long run equation [Dep. Var. = InFDI]

\begin{tabular}{lccc}
\hline & Annual & \multicolumn{2}{c}{ Quarterly } \\
\cline { 2 - 4 } & Model 1 & Model 2a & Model 2b \\
\hline InGDP & $0.3011^{* * *}$ & $0.9870 * * *$ & $0.9632 * * *$ \\
& $(14.3940)$ & $(6.2468)$ & $(6.1404)$ \\
InEXP & $0.1897^{* * *}$ & $0.1058^{* *}$ & $0.1017 * *$ \\
& $(16.0897)$ & $(2.2646)$ & $(2.4281)$ \\
InIQ & $0.4504^{* * *}$ & $0.5010^{* * *}$ & $0.4048^{* *}$ \\
& $(7.9626)$ & $(2.3702)$ & $(2.0734)$ \\
InIQ*GAP & $-0.0322^{* * *}$ & $-0.0388^{* * *}$ & $-0.0477 * * *$ \\
& $(-5.8471)$ & $(-2.4408)$ & $(-3.5911)$ \\
InINFRA & - & - & 0.0253 \\
InNATR & - & - & $(0.2360)$ \\
& & & -0.0276 \\
\hline
\end{tabular}

Note: $* *$ and $* * *$ denote significance at $5 \%$ and $1 \%$ critical values, respectively. Figure in () stands for t-value. 
finding confirmed our primary hypothesis that the effectiveness of IQ in attracting FDI will gradually be eroded if the IQ in competing countries is higher than that in the host small countries. The larger the gap of IQ, the larger would be the level of gradual ineffectiveness of IQ in host countries to be used as a means to attract more FDI inflows. At minimum, the model suggests that small countries can still rely on improvement in IQ as a means to attract and retain FDI inflows as long as the improvement can lead to a better level of IQ as compared to competing large countries' IQ level. This will turn the IQ gap (or GAP) to be negative and the interaction term will introduce positive effect to FDI inflows. Hence, positive upgrading of IQ level is still insufficient to guarantee huge or desirable amount of FDI inflows to host countries if the level of IQ in competing large countries remained higher.

On the insignificant effect of natural resources, Smith (2016) stated that while Africa is rich with natural resources such as oil, diamond, uranium, marine resources and so on, natural abundance is not enough to attract FDI for most countries in Africa. Smith (2016) further argued that to attract reasonably huge volume of FDI inflows, African countries need to establish and maintain political and macroeconomic stability as well as to design a policy environment conducive to investment. Although natural resources should invite more FDI, cross-country analyses suggest that prior to FDI, natural resources tend to fuel war and conflict, which in turn are unlikely to attract more FDI inflows (Collier \& Hoeffler, 2005; Fearon, 2005; Ross, 2004). Moreover, under the resource curse hypothesis, Poelhekke and Ploeg (2010) observed that resource abundance has a negative impact on aggregate FDI with initial negative effect on non-resource FDI. As for the insignificant role of infrastructure, several potential explanations are available. Firstly, the concept or definition of infrastructure is too broad. Different definition, scope or proxy may result in different results. For instance, the study by Kaur, Khatua and Yadav (2016) observed that railway transportation matters to lure FDI into India but currently this is not the case for air transportation and communication infrastructure. Similarly, Wekesa, Wawire and Kosimbei (2016) also argued that only improvement of current poor condition of all sorts of infrastructure, which include transport, communication, water and waste infrastructures can attract more FDI into Kenya. Although the study of Wekesa et al. (2016) is about Kenya, it is generally applicable to most developing countries and therefore, could be the reason of insignificant impact of infrastructure on FDI inflows.

As additional robustness test, we conduct a sub-sample analysis based on regions although this analysis could be suffering from low sample size. The results of ECT for each regional model suggest that all variables are cointegrated in every regional model. The error correction version of ARDL which is shown at the bottom of Table 6 confirms the existence of long-run relationship among the variables as all ECT have significant and negative coefficients. Moving on to our main interest, each regional long-run equation as shown in Table 6 highlights similar results as in pooled model. Positive GAP which means IQ in big countries is larger than IQ of surrounding small countries may erode the effectiveness of IQ in small countries in attracting the inflows of FDI. If the GAP is sufficiently big enough, the role of IQ in host country may not only totally disappear, but also turn to be negative. This conclusion is in line with Bénassy-Quéré et al. (2007) who stated that institutional distance is more important than the quality of 
Table 6. Regional long run equation for model 1 [Dep. Var. = InFDI]

\begin{tabular}{lcccc}
\hline & Latin America $^{\mathrm{a}}$ & ASEAN $^{\mathrm{b}}$ & South Asia $^{\mathrm{c}}$ & Transition $^{\mathrm{d}}$ \\
\cline { 2 - 5 } & \multicolumn{4}{c}{ Long-run Equation: } \\
\cline { 2 - 5 } InGDP & $-0.3097^{* * *}$ & $0.5215^{* * *}$ & $1.5133^{* * *}$ & $0.9404^{*}$ \\
& $(-2.6643)$ & $(3.5570)$ & $(5.2795)$ & $(2.4551)$ \\
InEXP & $0.1623^{* * *}$ & $0.2219^{* * *}$ & 0.0012 & 0.0594 \\
& $(6.9194)$ & $(4.0451)$ & $(0.0154)$ & $(0.6031)$ \\
InIQ & $0.7221^{* * *}$ & $0.7931^{* * *}$ & $0.2062^{*}$ & $0.6276^{* *}$ \\
& $(6.6449)$ & $(2.9359)$ & $(1.9348)$ & $(2.5532)$ \\
InIQ*GAP & $-0.0346^{* * *}$ & $-0.0118^{*}$ & $-0.0609 *$ & $-0.0576^{* *}$ \\
& $(-6.2950)$ & $(-1.9704)$ & $(-1.8949)$ & $(-2.4848)$ \\
\hline
\end{tabular}

Error Correction Model:

a $\Delta \ln F D I=2.84^{*}-0.23 E C T_{t-1}^{*}+1.04 \Delta \ln G D P^{*}-0.07 \Delta \ln E X P-0.28 \Delta \ln 1 Q+0.43 \Delta[\ln I Q * G A P]$

b $\Delta \ln F D I=-5.91^{* * *}-0.60 E C T_{t-1}^{* *}+1.77 \Delta \ln G D P-0.73 \Delta \ln E X P-0.81 \Delta \ln I Q-0.16 \Delta[\ln I Q * G A P]$

c $\Delta \ln F D I=-8.67^{* * *}-0.80 E C T_{t-1}^{* * *}+1.14 \Delta \ln G D P-0.43 \Delta \ln E X P-6.02 \Delta \ln I Q-4.62 \Delta[\ln I Q * G A P]$

d $\Delta \ln F D I=-1.97^{* * *}-0.11 E C T_{t-1}^{* * *}+2.60 \Delta \ln G D P^{*}-0.38 \Delta \ln E X P^{*}-0.04 \Delta \ln I Q-0.10 \Delta[\ln I Q * G A P]$

\begin{tabular}{lcccc}
\hline & \multicolumn{4}{c}{ Bound test: } \\
\cline { 2 - 5 } F-value & $7.01^{* * *}$ & $6.32^{* * *}$ & $7.16^{* * *}$ & $6.11^{* * *}$ \\
\hline \multirow{3}{*}{ Normality } & 5.61 & \multicolumn{3}{c}{ Diagnostic tests for error correction model: } \\
\cline { 2 - 5 } & 2.3594 & 1.0339 & 2.7025 & 1.1974 \\
Serial correlation & $(0.1387)$ & $(0.5972)$ & $(0.2581)$ & $(0.2874)$ \\
& 1.3709 & 0.1295 & 3.4015 & 0.1982 \\
Heterogeneity & $(0.5041)$ & $(0.7221)$ & $(0.0657)$ & $(0.8219)$ \\
& 0.7674 & 0.5773 & 1.9893 & 0.6103 \\
& $(0.3932)$ & $(0.4538)$ & $(0.1615)$ & $(0.4394)$ \\
\hline
\end{tabular}

Note: $*, * *$ and $* * *$ denote significant at $10 \%, 5 \%$ and $1 \%$ critical values, respectively. Figure in ( ) stands for t-statistic. Jarque-Bera test is the test for normality. Breusch-Pagan LM test is the test for serial correlation. White test is the test statistic for possible presence of heteroscedasticity. Stability test is conducted by using CUSUM test and available upon request.

institutions in the host country, especially to attract FDI from developed countries such as OECD countries.

The insignificant effect of exports in the case of South Asian transition economies could be surprising and against conventional wisdom. This could be because the level of trade in this region is considered as low. The latest statistics by World Integrated Trade Solution show that South Asian exports as a percentage of GDP for the region stood at less than 20 percent in 2016. Although much higher (64 percent) in the case of transition 
economies, mainly the Central and Eastern European countries, the biggest issue is that most of these countries are still struggling to achieve 50 percent level of exports relative to GDP. Only Estonia and Hungary are relatively successful in promoting exports.

\section{Conclusion}

In this paper, the relationship between FDI and IQ is examined taking into account the moderating effect of large competing countries' IQ as well as other standard explanatory variables as control variables. Pooled mean group (PMG) estimator due to Pesaran et al. (1999) is employed to deal with heterogeneity problems but can offer homogenous long run relationship. During the study period between 1996 and 2012, all small countries surrounding the large countries in four regions, namely Latin American, South Asian, ASEAN and transition economies are able to use IQ as their strategy to lure more FDI inflows. However, the ability or effectiveness of IQ in attracting FDI inflows is subject to the level of IQ in the competing large countries such as Brazil, Russia, India and China. Hence, while good IQ is considered as a necessary condition for FDI inflows, 'mere' improvement in IQ may be helpful but is not a sufficient condition to assure a 'must' inflow of FDI.

\section{References}

Aleksynska, M., \& Havrylchyk, O. (2013). FDI from the south: The role of institutional distance and natural resources. European Journal of Political Economy, 29(March), 38-53. https://doi. org/10.1016/j.ejpoleco.2012.09.001

Alfaro, L., Chanda, A., Kalemli-Ozcan, S., \& Sayek, S. (2004). FDI and economic growth: The role of local financial markets. Journal of International Economics, 64(1), 89-112. https://doi. org/10.1016/S0022-1996(03)00081-3

Alfaro, L., Kalemli-Ozcan, S., \& Volosovych, V. (2008). Why doesn't capital flow from rich to poor countries? An empirical investigation. The Review of Economics and Statistics, 90(2), 347-368. https://doi.org/10.1162/rest.90.2.347

Asiedu, E. (2004). Policy reform and foreign direct investment in Africa: Absolute progress but relative decline. Development Policy Review, 22(1), 41-48. https://doi.org/10.1111/j.14678659.2004.00237.x

Asiedu, E. (2006). Foreign direct investment in Africa: The role of natural resources, market size, government policy, institutions and political instability. The World Economy, 29(1), 63-77. https://doi.org/10.1111/j.1467-9701.2006.00758.x

Asiedu, E., \& Lien, D. (2011). Democracy, foreign direct investment and natural resources. Journal of International Economics, 84(1), 99-111. https://doi.org/10.1016/j.jinteco.2010.12.001

Bénassy-Quéré, A., Coupet, M., \& Mayer, T. (2007). Institutional determinants of foreign direct investment. The World Economy, 30(5), 764-782. https://doi.org/10.1111/j.14679701.2007.01022.x

Bojnec, Š., Fertő, I., \& Fogarasi, J. (2014). Quality of institutions and the BRIC countries agro-food exports. China Agricultural Economic Review, 6(3), 379-394. https://doi.org/10.1108/CAER02-2013-0034

Breitung, J. (2000). The local power of some unit root tests for panel data. In B.H. Baltagi, T.B. Fomby \& R.C. Hill (Eds.), Nonstationary panels, panel cointegration, and dynamic panels (Advances in econometrics, Vol. 15) (pp. 161-178). Bingley, UK: Emerald Publishing. 
Bronzini, R. (2007). FDI inflows, agglomeration and host country firms' size: Evidence from Italy. Regional Studies, 41(7), 963-978. https://doi.org/10.1080/00343400701281618

Buch, C.M., \& Lipponer, A. (2007). FDI versus exports: Evidence from German banks. Journal of Banking \& Finance, 31(3), 805-826. https://doi.org/10.1016/j.jbankfin.2006.07.004

Buchanan, B.G., Le, Q.V., \& Rishi, M. (2012). Foreign direct investment and institutional quality: Some empirical evidence. International Review of Financial Analysis, 21(January), 81-89. https://doi.org/10.1016/j.irfa.2011.10.001

Busse, M., \& Hefeker, C. (2007). Political risk, institutions and foreign direct investment. European Journal of Political Economy, 23(2), 397-415. https://doi.org/10.1016/j.ejpoleco. 2006.02.003

Cezar, R., \& Escobar, O.R. (2015). Institutional distance and foreign direct investment. Review of World Economics, 151(4), 713-733. https://doi.org/10.1007/s10290-015-0227-8

Cleeve, E. (2008). How effective are fiscal incentives to attract FDI to Sub-Saharan Africa? Journal of Developing Areas, 42(1), 135-153.

Cole, M.A., Elliott, R.J., \& Zhang, J. (2009). Corruption, governance and FDI location in China: A province-level analysis. The Journal of Development Studies, 45(9), 1494-1512. https://doi. org/10.1080/00220380902890276

Collier, P., \& Hoeffler, A. (2005). Resource rents, governance, and conflict. Journal of Conflict Resolution, 49(4), 625-633. https://doi.org/10.1177/0022002705277551

Daniele, V., \& Marani, U. (2011). Organized crime, the quality of local institutions and FDI in Italy: A panel data analysis. European Journal of Political Economy, 27(1), 132-142. https://doi. org/10.1016/j.ejpoleco.2010.04.003

Davidson, R., \& MacKinnon, J.G. (2004). Econometric theory and methods. Oxford: Oxford University Press.

Du, J., Lu, Y., \& Tao, Z (2008). FDI location choice: Agglomeration vs institutions. International Journal of Finance and Economics, 13(1), 92-107. https://doi.org/10.1002/ijfe.348

Eichengreen, B., \& Tong, H. (2007). Is China's FDI coming at the expense of other countries? Journal of the Japanese and International Economies, 21(2), 153-172. https://doi.org/ 10.1016/j.jjie.2006.07.001

Engle, R.F., \& Granger, C.W.J. (1987). Cointegration and error correction: Representation, estimation and testing. Econometrica, 55(2), 251-276. https://doi.org/10.2307/1913236

Fearon, J.D. (2005). Primary commodities exports and civil war. Journal of Conflict Resolution, 49(4), 483-507. https://doi.org/10.1177/0022002705277544

Fosu, O-A.E., \& Magnus, F.J. (2006). Bounds testing approach to cointegration: An examination of foreign direct investment trade and growth relationships. American Journal of Applied Sciences, 3(11), 2079-2085.

Globerman, S., \& Shapiro, D. (2002). Global foreign direct investment flows: The role of governance infrastructure. World Development, 30(11), 1899-1919. https://doi.org/10.1016/ S0305-750X(02)00110-9

Goswami, G.G., \& Haider, S. (2014). Does political risk deter FDI inflow? An analytical approach using panel data and factor analysis. Journal of Economic Studies, 41(2), 233-252. https://doi. org/10.1108/JES-03-2012-0041

Habib, M., \& Zurawicki, L. (2002). Corruption and foreign direct investment. Journal of International Business Studies, 33(2), 291-307.

Hong, J. (2008). WTO accession and foreign direct investment in China. Journal of Chinese Economic and Foreign Trade Studies, 1(2), 136-147. https://doi.org/10.1108/175444008 10884709

Hyun, H.J. (2006). Quality of institutions and foreign direct investment in developing countries: Causality tests for cross-country panels. Journal of Business Economics and Management, 7(3), 103-110. 
Im, K.S, Pesaran, M.H., \& Shin, Y. (2003). Testing for units roots in heterogeneous panels. Journal of Econometrics, 115(1), 53-74. https://doi.org/10.1016/S0304-4076(03)00092-7

Johansen, S., \& Juselius, K. (1990). Maximum likelihood estimation and inference on cointegration - with applications to the demand for money. Oxford Bulletin of Economics and Statistics, 52(2), 169-210. https://doi.org/10.1111/j.1468-0084.1990.mp52002003.x

Ji, K., Magnus, J.R., \& Wang, W. (2014). Natural resources, institutional quality, and economic growth in China. Environmental and Resource Economics, 57(3), 323-343. https://doi. org/10.1007/s10640-013-9673-8

Julio, B., \& Yook, Y. (2016). Policy uncertainty, irreversibility, and cross-border flows of capital. Journal of International Economics, 103(November), 13-26. https://doi.org/10.1016/ j.jinteco.2016.08.004

Kao, C., \& Chiang, M-H. (2001). On the estimation and inference of a cointegrated regression in panel data. In B.H. Baltagi, T.B. Fomby, \& R.C. Hill (Eds.), Nonstationary panels, panel cointegration, and dynamic panels: A survey (Advances in econometrics, Volume 15) (pp. 179-222). Bingley: Emerald Publishing Limited.

Kaur, M., Khatua, A., \& Yadav, S.S. (2016). Infrastructure development and FDI inflow to developing economies: Evidence from India. Thunderbird International Business Review, 58(6), 555-563. https://doi.org/10.1002/tie.21784

Kinda, T. (2016). The quest for non-resource-based FDI: Do taxes matter? Macroeconomics and Finance in Emerging Market Economies, 9(3), 1-18. https://doi.org/10.1080/17520843.2016. 1244095

Koehler, A.B., \& Murphree, E.S. (1988). A comparison of the Akaike and Schwarz criteria for selecting model order. Journal of the Royal Statistical Society: Series C (Applied Statistics), 37(2), 187-195. https://doi.org/10.2307/2347338

Kremers, J.J., Ericsson, N.R., \& Dolado, J.J. (1992). The power of cointegration tests. Oxford Bulletin of Economics and Statistics, 54(3), 325-348. https://doi.org/10.1111/j.1468-0084. 1992.tb00005.x

Levin, A., Lin, C-F., \& Chu, C-S. (2002). Unit root test in panel data: Asymptotic and finite sample properties. Journal of Econometrics, 108(1), 1-24. https://doi.org/10.1016/S03044076(01)00098-7

Lipsey, R. (1999). The location and characteristics of U.S. affiliates in Asia (NBER Working Paper Series No. 6876). Cambridge MA: National Bureau of Economic Research. https://doi. org $/ 10.3386 /$ w6876

Liu, L., Chow, K., \& Li, U. (2007). Has China crowded out foreign direct investment from its developing East Asian neighbors? China and World Economy, 15(3), 70-88. https://doi. org/10.1111/j.1749-124X.2007.00069.x

Loree, D.W., \& Guisinger, S.E. (1995). Policy and non-policy determinants of U.S. equity foreign direct investment. Journal of International Business Studies, 26(2), 281-299.

Masron, T.A. (2017). Relative institutional quality and FDI inflows in ASEAN countries. Journal of Economic Studies, 44(1), 115-137. https://doi.org/10.1108/JES-04-2015-0067

Masron, T.A., \& Naseem, N.A.M. (2017). Institutional quality and foreign direct investment in ASEAN. Institutions and Economies, 9(4), 5-30.

Masron, T.A., \& Nor, E. (2013). FDI in ASEAN-8: Does institutional quality matter? Applied Economics Letters, 20(2), 186-189. https://doi.org/10.1080/13504851.2012.687090

Narayan, P.K., \& Smyth, R. (2006). Higher education, real income and real investment in China: Evidence from Granger causality tests. Education Economics, 14(1), 107-125. https://doi. org/10.1080/09645290500481931

Narayan, S., \& Narayan, P.K. (2005). An empirical analysis of Fiji's import demand function. Journal of Economic Studies, 32(2), 158-168. https://doi.org/10.1108/01443580510600931 
Ndikumana, L., \& Verick, S. (2008). The linkages between FDI and domestic investment: Unravelling the developmental impact of foreign investment in Sub-Saharan Africa. Development Policy Review, 26(6), 713-726. https://doi.org/10.1111/j.1467-7679.2008.00430.x

Neumayer, E., \& Spess, L. (2005). Do bilateral investment treaties increase foreign direct investment to developing countries? World Development, 33(10), 1567-1585. https://doi. org/10.1016/j.worlddev.2005.07.001

OECD. (2000). Main determinants and impacts of foreign direct investment on China's economy (OECD Working Papers on International Investment No. 2000/04), Paris: OECD Publishing. https://doi.org/10.1787/321677880185

Oluwatobi, S., Efobi, U., Olurinola, I., \& Alege, P. (2015). Innovation in Africa: Why institutions matter. South African Journal of Economics, 83(3), 390-410. https://doi.org/10.1111/saje.12071

Omtzigt, P., \& Fachin, S. (2006). The size and power of bootstrap and Bartlett-corrected tests of hypotheses on the cointegrating vector. Econometric Reviews, 25(1), 41-60. https://doi. org/10.1080/07474930500545439

Papaioannou, E. (2009). What drives international financial flows? Politics, institutions and other determinants. Journal of Development Economics, 88(2), 269-281. https://doi.org/10.1016/j. jdeveco.2008.04.001

Pedroni, P. (1999). Critical values for cointegration tests in heterogeneous panels with multiple regressors. Oxford Bulletin of Economics and Statistics, 61(S1), 653-670.

Pesaran, M.H., \& Shin, Y. (1995). An autoregressive distributed lag modelling approach to cointegration analysis (DAE Working Paper No. 9514). Cambridge: Department of Applied Economics, University of Cambridge. https://doi.org/10.1017/CCOL521633230.011

Pesaran, H., Shin, Y., \& Smith, R. (1999). Pooled mean group estimation of dynamic heterogeneous panels. Journal of the American Statistical Association, 94(446), 621-634. https://doi. org $/ 10.2307 / 2670182$

Pesaran, M.H., Shin, Y., \& Smith, R. (2001). Bounds testing approaches to the analysis of level relationships. Journal of Applied Econometrics, 16(3), 289-326. https://doi.org/10.1002/ jae.616

Poelhekke, S., \& Ploeg, F. van der (2010). Do natural resources attract FDI? Evidence from nonstationary sector level data (De Nederlandsche Bank (DNB) Working Paper No. 266/2010), Amsterdam: De Nederlandsche Bank. https://doi.org/10.2139/ssrn.1950092

Ravenhill, J. (2006). Is China an economic threat to Southeast Asia? Asian Survey, 46(5), 653-674. https://doi.org/10.1525/as.2006.46.5.653

Robbins, G., \& Perkins, D. (2012). Mining FDI and infrastructure development on Africa's East Coast: Examining the recent experience of Tanzania and Mozambique. Journal of International Development, 24(2), 220-236. https://doi.org/10.1002/jid.2817

Ross, M.L. (2004). What do we really know about natural resources and civil war? Journal of Peace Research, 41(3), 337-356. https://doi.org/10.1177/0022343304043773

Sánchez-Martín, M.E., de Arce, R., \& Escribano, G. (2014). Do changes in the rules of the game affect FDI flows in Latin America? A look at the macroeconomic, institutional and regional integration determinants of FDI. European Journal of Political Economy, 34(June), 279-299. https://doi.org/10.1016/j.ejpoleco.2014.02.001

Schneider, F., \& Frey, B.S. (1985). Economic and political determinants of foreign direct investment. World Development, 13(2), 161-175. https://doi.org/10.1016/0305-750X(85)90002-6

Shah, S.H., Ahmad, M.H., \& Ahmed, Q.M. (2016). The nexus between sectoral FDI and institutional quality: Empirical evidence from Pakistan. Applied Economics, 48(17), 1591-1601. https:// doi.org/10.1080/00036846.2015.1103039

Smith, M.S. (2016). Beyond the 'African tragedy': Discourses on development and the global economy. New York: Routledge. 
Teixeira, A.A., \& Guimarães, L. (2015). Corruption and FDI: Does the use of distinct proxies for corruption matter? Journal of African Business, 16(1-2), 159-179. https://doi.org/10.1080/15 228916.2015.1027881

Torrisi, C.R. (1985). The determinants of direct foreign investment in a small LDC. Journal of Economic Development, 10(1), 29-45.

Tran, T.Q. (2009). Sudden surge in FDI and infrastructure bottlenecks: The case in Vietnam. ASEAN Economic Bulletin, 26(1), 58-76.

Tuan, C., \& Ng, L.F. (2004). Manufacturing agglomeration as incentives to Asian FDI in China after WTO. Journal of Asian Economics, 15(4), 673-693. https://doi.org/10.1016/j.asieco. 2004.05.014

UNCTAD. (2014). UNCTADstat. Retrieved from http://unctadstat.unctad.org/

Wang, C., Wei, Y., \& Liu, X. (2007). Does China rival its neighboring economies for inward FDI? Transnational Corporations, 16(3), 35-60.

Wekesa, C.T., Wawire, N.H., \& Kosimbei, G. (2016). Effects of infrastructure development on foreign direct investment in Kenya. Journal of Infrastructure Development, 8(2), 93-110. https://doi.org/10.1177/0974930616667875

Wheeler, D., \& Mody, A. (1992). International investment location decisions: The case of U.S. firms. Journal of International Economics, 33(1-2), 57-76. https://doi.org/10.1016/00221996(92)90050-T

World Bank. (2010). Foreign direct investment - the China story. Retrieved from http://www. worldbank.org/en/news/feature/2010/07/16/foreign-direct-investment-china-story

World Bank. (2014a). World development indicators. Retrieved from https://data.worldbank.org/ products/wdi

World Bank. (2014b). Worldwide governance indicators. Retrieved from https://datacatalog. worldbank.org/dataset/worldwide-governance-indicators

Yang, Y. (2006). China's integration into the world economy: Implications for developing countries. Asian-Pacific Economic Literature, 20(1), 40-56. https://doi.org/10.1111/j.1467-8411.2006. 00177.x

Zhuang, J., de Dios, E., \& Martin, A.L. (2010). Governance and institutional quality and the links with economic growth and income inequality: With special reference to developing Asia (ADB Economics Working Paper Series No. 193). Manila: Asian Development Bank. https://doi. org/10.2139/ssrn.1619116 